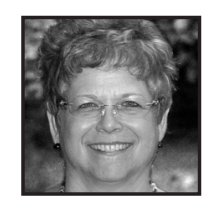

\title{
Creating Community Connections and Partnerships for Transformative Social Change
}

\author{
Heidi R. Bacon, Southern Illinois University-Carbondale
}

\begin{abstract}
In this article, I share my experiences connecting with community as a high school teacher, a community literacy developer, and a teacher educator. I describe three partnerships that created conditions for transformative change, challenging boundaries of traditional schooling by providing spaces for shared knowledge and meaning making. The experiences that undergird these partnerships present a counter story to deficit discourses and narratives of school failure. They highlight possibilities for investing in our collective future and demonstrate the capacity of individuals to build community and enact learning landscapes to bring about a more socially just world.
\end{abstract}

learned firsthand about the importance of community as a second-year high school teacher. I was well acquainted with giving back and paying it forward, but it was not until I began teaching at an urban charter school that I came to understand the magnitude of what 13th century Persian poet Jalal ad-Din Muhammad Rumi meant by his quote: "Let the beauty of what you love be what you do." Until that moment in time, I had never fully conceptualized the kind of connectedness that "builds and sustains community" (hooks, 2003, p. xv). It is this belonging and connectedness that enables the kind of outreach that fosters participatory literacy research, and it is always about doing with and not doing for. Gregory (2013) makes plain that "we always need to ask ourselves how can I draw on the assets of my community?" (p. 470).

In this article, I share my experiences connecting with community as a high school teacher and community literacy developer in a large Southwestern city and 
later as a teacher educator in a small rural city in the Midwest. I draw on the work of Paulo Freire (2000) who encouraged us to read the world to read the word, thereby creating a critical consciousness of action and reflection that constitutes praxis. I further illustrate how collaborative partnerships and outreach can inspire us to actively create conditions for change, shifting prevailing discourses and disrupting typical stories, which Gee (2014) describes as the kind of commonly accepted stories that tend to classify and group individuals and communities according to master narratives that are often stereotypical in nature.

\section{Story as Meaning Making}

Telling stories helps us construct meaningful selves and realities (see Chase, 2011). We tell stories to make sense of our world. Short (2012) refers to story as "world making," illustrating the power of story to "make connections, form relationships, and create community" (p. 9). According to Short (2013), "Stories bind us together in community" (p. 114). Conversely, the public story about education consists largely of a master narrative framed in terms of crisis, achievement gaps, and school failure (Short, 2013). Too often, these stories are focused on what individuals cannot do as indicators of their future potential (McDermott \& Raley, 2009), limiting possibilities and their imagined communities (Norton, 2013).

\section{Complicating the Narrative}

I begin by unpacking the notion of community. The word "community" is used in a variety of contexts, leading Barton and Hamilton (1998) to refer to the term as "amorphous" (p. 251). Moje (2000) takes up the question of what constitutes a community. She points to communities as more than bounded geographical spaces or stable, relatively fixed, homogenous groups. Instead, Moje paints a picture of shifting school and neighborhood demographics that complicate commonly held beliefs and underscore the importance of recognizing the multiple and unique communities that exist within communities, a notion that Barton and Hamilton refer to as "communities of interest" (p. 15).

In addition to the complexities of defining community, another well-intentioned, yet problematic theme pertaining to literacy research in communities has concentrated 
on "bringing people to literacy" (Reder, 2007). For decades, literacy programs have focused on the notion of literacy as an equalizer while neglecting the inequities of literacy in a socially stratified society. In contrast, "bringing literacy to people" centers literacy instruction and practices within the setting and context of the learner, using what Street (2004; see also Purcell-Gates, Degener, \& Jacobson, 2001) refers to as "real," authentic materials that people encounter and use in every-day life. To counter the practice of "bringing people to literacy," Street encourages literacy researchers to adopt an ethnographic approach before implementing programs in communities to become knowledgeable about the social practices or local funds of knowledge, an approach that uses ethnographic methods to provide a more accurate portrayal of households within their social and historical contexts (Moll, Amanti, Neff, \& González, 1992). Street maintains that ethnographic approaches to literacy and community "make the invisible visible" (p. 57).

To this effect, Orellana and Gutiérrez (2006) point out that most research starts with a problem statement. We frame our articles using statistics that portray working-class and nondominant communities in incomplete and normative ways. These accounts are problematic because they fail to acknowledge how to respond by engaging in innovation, creativity, and collaboration. hooks (2003) asserts that teaching beyond the container of the classroom (see Leander, Phillips, Headrick-Taylor, Nespor, \& Lewis, 2010) means engaging the "theory we write about in academia with non-academic audiences" (p. xi) in ways that are mutually exciting and constitutive.

In keeping with Orellana and Gutiérrez and other sociocultural literacy researchers, I present my own work to challenge and shift perceptions of community and to hone in on what Heath (2010) calls the potential of organizations to "accommodate diversity, stimulate creativity, respond quickly, and build leadership across multiple roles" (p. 22). While Heath differentiates schools from organizations, I highlight the potential of organizations to work hand in hand with schools to harness the capacity of individuals, not to provide quick-fix, one-size-fits-all initiatives that serve the greatest number for the greatest good (Bacon, 2014), but rather to represent the "promise and potential" (Heath, 2010, p. 23) of our society. Moving beyond school as container (Leander et al., 2010) and extending out into community spaces, these kinds of experiences can open new arenas for "engaging with and learning from the community" (Dozier, Johnston, \& Rogers, 2006, p. 171).

I now chronicle three partnerships that link school, university, and community in meaningful ways. I describe my experiences with a school-based service learning program, a community-based literacy initiative, and a university-community 
partnership in which I am currently engaged. My intent is not to romanticize community research (Moje, 2000), but rather to emphasize the power of social networks that foster community connections. These stories offer a counternarrative to typical stories that frame nondominant communities in normative ways. Each story illustrates the importance of seeking out the community's needs, as defined by the community, without making assumptions about what those needs might be. The wherewithal to seek and listen can forge the kind of ties and awareness that is capable of bringing about transformative change (see Lin, 2001; Small, 2009).

\section{Connecting School and Community: School-Based Service Learning}

Service learning was a new concept for me. As a middle-aged white teacher, I initially struggled to connect and build relationships with students. I tended to be perceived as strict, demanding, and someone who expected too much of students. Service learning created a bridge that enabled me and my students to get to know each other and engage in a reciprocity of teaching and learning.

How did this all come about? Unbeknownst to staff, the school had received a Learn and Serve grant (see the Corporation for National and Community Service, 2011). An administrative leadership change necessitated a change in sponsorship for the new service learning initiative. Other faculty were hesitant to take on the role of coordinator, as student behavior could be challenging at the best of times, and I admit that I too had mixed feelings. I was afraid that students would not want to work with me; however, I agreed to develop and coordinate the service learning program, which helped to build collaborative partnerships with students, school, and community.

As such, I found myself chaperoning six students on a three-day trip to service learning camp. The state required Learn and Serve grantees, faculty sponsors, and students to attend the yearly camp in order to learn how to plan and conduct service learning projects and meet grant deliverables. Traveling together in a 15-passenger van and working side by side with students for three days helped us bond in ways that were inhibited by the formal structure of schooling. Our shared engagement and joint enterprise formed the genesis of a youth-led service community of practice (see Lave \& Wenger, 1991) that continued for six years. 
While not new, service learning has proliferated at the college level. It has gained increasing currency in K-12 educational settings. According to the Corporation for National and Community Service (2011), ${ }^{1}$ one in four elementary and secondary schools engage in service learning, where students use "their knowledge and skills to improve their communities" and "make the connection between learning and doing" (para. 1).

Service learning is designed to link service to the curriculum in ways that make learning relevant to students' lives, experiences, and literacies. It is not, however, without critique. Swaminathan (2007) makes clear that service learning should not be equated with charity, nor should it maintain hierarchical binaries between those who are serving and those who are served. He points to misunderstandings between social justice teachers and community supervisors and advocates for involving community partners in the planning of service learning experiences.

\section{Creating Conditions for Service and Learning}

As stated above, Street (2004) writes that an ethnographic approach to literacy programs entails researching social practices in the community that initially may or may not involve literacy. The partners in service program did not specifically focus on literacy; however, students engaged in the social practice of literacy in every project they undertook.

The school ran on an advisory system, which was conducive to conducting ongoing service projects made possible through various social networks and ties. Social ties are critical to making community connections. Small (2009) contends that whether people as social actors make ties at all depends on opportunities to interact with others and the frequency and duration of those interactions while performing certain activities. The local neighborhood association served as a broker with other organizations to connect students with opportunities for service both in and out of the neighborhood.

The partners in service program kicked off with a school-wide inquiry into community development and asset mapping (Kretzmann \& McKnight, 1993) where students met with community leaders and organized a service learning day. Advisory groups broke up into teams and partnered with community members to walk the school's surrounding neighborhood. The students met with community 
leaders and later attended Neighborhood Association meetings to inquire how they could best serve the neighborhood.

The students adopted a local care home in the neighborhood for low-income elderly residents. They partnered with the neighborhood association on a grant to house a small computer lab at the home with several computers, a scanner, and a printer. Students taught residents how to use email and Microsoft Office applications. They helped create bulletins for devotionals. They visited weekly year-round to have dinner with residents. After dinner, they read to residents, played board games with them, and talked. One of the residents was a retired Air Force fighter pilot who flew sorties during World War II; he shared his experiences with a young man as they played chess, a student who later joined the army and served overseas in Iraq.

The neighborhood was also home to a children's shelter. One of the advisories researched homelessness and domestic violence and adopted the children's shelter. They raised funds for the shelter and recorded books on tape for the children. Another group of students partnered with a city program to plant trees in the neighborhood. They negotiated with the city to waive the fees for trees and worked with the neighborhood association to identify neighbors who wanted trees. The students researched how to plant the trees in the desert soil and coordinated the delivery and planting of over 40 trees in the neighborhood.

Over the course of six years, the partners in service program collaborated with Habitat for Humanity to build houses in under-resourced neighborhoods, traveled to New Orleans to participate in the clean-up following the aftermath of Katrina, and partnered with Humane Borders and the local community college campus day care center. All in all, students created direct and indirect partnerships with approximately 20 organizations.

\section{Impact on Lives and Learning}

The partners in service program built strong community-school and intergenerational relationships. The neighborhood reported less graffiti. There were fewer neighborhood complaints about students. Students were increasingly seen as assets and resources. There were modest gains in attendance, as students reported coming to school because their service projects were meaningful and required their presence. Teachers came to see service learning as worthwhile, and students felt 
valued. The partners in service program received local, state, and federal recognition, culminating in a visit from the American Youth Policy Forum. Lastly, student reflections indicated that service learning enriched their lives and provided the motivational means to help them succeed and grow both personally and academically.

\section{The Women's Literacy Initiative}

I left the charter school at the end of 2010 to concentrate on my doctoral studies. I was hired as a project lead by the local literacy coalition to coordinate a community literacy outreach initiative. After an extensive survey of 18 neighborhoods, two neighborhoods came forward, indicating their desire to become literacy zones: "geographic areas in which neighborhood stakeholders, school leaders and teachers, local elected officials, business leaders and literacy service providers join efforts to significantly enhance literacy outcomes" (Bacon, 2014, p. 18). Under the direction of my major advisor, I worked with two master's students, former Peace Corps members, to map the assets of these two neighborhoods, the city's first literacy zones.

\section{Listening to Community}

The asset map represented the observations and beliefs of community members from all walks of life. We came to understand through a series of community interviews that the larger of the two communities was fed up with outsiders who used demographic data to determine neighborhood needs and obtain funding to conduct programs. Neighborhood residents expressed concerns that the programs were more about fixing them than addressing issues of (in)equity in the neighborhood (Bacon, 2014).

Unfortunately, this is not uncommon. Moje (2000) found the notion of "community as a problem to be fixed" (p. 93) well represented in the literature on literacy programs. In response, the neighborhood literacy zone sought to grow its own programs and develop local volunteers to reduce the need for community outsiders. The neighborhood requested the literacy coalition's help, and a number of neighborhood programs were created through innovative, collaborative partnerships. The neighborhood established a self-governing literacy council that advised on neighborhood projects. The Women's Literacy Initiative $\left(\mathrm{WLI}^{2}\right)$, a three-year women's literacy and empowerment program, grew out of this work.

The literacy zone was rich in assets: intergenerational families, stable home ownership, strong, involved leadership, and an abundance of neighborhood pride. 
Neighborhood insiders viewed literacy as a challenge in that approximately $46 \%$ of residents over 25 did not have a high school credential or GED. Thus, with the neighborhood's blessing, the literacy coalition sought funding from a women's foundation to start the WLI. The WLI comprised a multi-partner collaborative partnership that included: the literacy coalition, the university's college of education, the local community college adult education center, the neighborhood branch library, and the local neighborhood association. Funding was obtained in summer of 2010, and my close colleague (a long-time adult educator and basic literacy program manager) and I developed and co-coordinated the literacy initiative during its first two years.

\section{Creating an Asset-Based Community Literacy Initiative}

The WLI trained neighborhood women with GEDs as literacy tutors. After 20 hours of training, tutors were matched with women from the local adult education center who were working on their GEDs. Grant funds were used to pay tutors and provide transportation and childcare stipends for tutors and students. Both tutors and students participated in bi-weekly mentoring. Tutoring and mentoring took place over 20 weeks. For students who passed the Official Practice Tests, the WLI paid their GED test fees. Tutors who completed their tutoring and mentoring hours and students who passed the GED were eligible for \$250 scholarships to the local community college. Upon receipt of the scholarship, recipients met with a dedicated transition counselor to support them as they entered postsecondary education.

\section{Impact of Community Literacy Initiative}

The program served over 60 tutors and students over the three-year period. Approximately 15 women earned their GEDs, and 18 women transitioned to college. All reported new understandings of literacy in practice and increased confidence. Mothers did not wait to be matched with students; they went home and implemented the strategies they were learning with their children, developing reading routines and shifting their literacy practices in the home. The women visited the library, checked out books, and read with their children.

Tutors bonded with students, and students looked up to their tutors as mentors, someone who had been there and who understood. Like the service learning students, the tutors saw their work as important. Melissa, a tutor, shares what the WLI meant to her: "My inspiration comes from really helping somebody else 
because I was there, and I wish that there had been a program out there when I was going through this. It just inspires me to go help somebody." Most notably, the tutors took on community leadership roles. They volunteered in the community, tutored extended family, and served as spokeswomen for the WLI, telling their stories and advocating for women's and family literacy.

The road is difficult for women who have dropped out of high school. Albertini (2009) and Reder (2010) point out that adjustments in the economy have resulted in higher unemployment and significant reductions in the availability of jobs for high school dropouts. Albertini calls on literacy providers and other professionals to develop creative and effective services for women and provide "networks of support in workplaces and communities" (p. 24). The women's experiences in the WLI demonstrate the importance of establishing social networks that advantage literacy and building in supports that create more equitable learning environments.

\section{Connecting With Rural Communities}

My position as an assistant professor brought me back to the Midwest, America's Heartland. Having grown up in a large Midwestern industrial city, I was unaccustomed to living in a rural area. I wondered how I could ever develop community ties that extended across five counties. A short, but incomplete, answer is that I talked to students and colleagues and asked a lot of questions. These conversations eventually led me to a rural migrant/farm worker community south of where I lived and worked. As this work continues to be a work in progress, I briefly share a story from this summer.

The migrant/farm worker community is a tightly knit community where community life and rhythms ebb and flow through the heart of a community organization, which I refer to as the Agricultural Worker's Center $\left(\mathrm{AWC}^{3}\right)$. The AWC offers afterschool tutoring, GED classes in Spanish, and sponsors a host of programs for children, adults, and families. Staff provide translation services and help families navigate forms and bureaucracies, always in an advocacy role. 


\section{Practicing Culturally Relevant Pedagogy}

Outside of a few migrant/farm worker communities and the university community, the five-county area is largely homogenous. Local pre- and in-service teachers come from largely white towns and have little experience with diversity unless they have relocated to the area from somewhere else. Partnering with the AWC has opened new avenues for intercultural awareness and understandings.

Gay (2013) explains that, "culturally relevant teaching foregrounds the positive learning possibilities of marginalized students and their heritage groups instead of belaboring their problems and pathologies" (pp. 50-51). This was made evident earlier this summer when my students and I partnered with the AWC to take the advanced diagnostic teaching of reading course out to the AWC, rather than meet at the university.

The AWC had contacted me about several students who were striving readers. Staff were worried about the children, so having the class meet at the AWC was mutually beneficial. Teachers had students to tutor, and students benefitted from working with teachers who were working on reading teacher/reading specialist endorsements. The welcoming attitude of the AWC and the children made a deep impression on the teachers, who expressed feeling out of their comfort zone. Their experiences at the Center forced them to critically examine their assumptions about working with language minority students and families.

\section{Reflecting on Practice}

In their reflections, the teachers shared that they found the children appreciative, attentive, and eager to learn. The teachers took time to get to know the children. They realized from working with the children that the children's instruction emphasized correctness and reading as decoding. The teachers used assessment results to shift instruction working from what the children were doing well to address areas of need. In the process, I noticed a shift in their discourses, how they talked about students and parents.

The teachers commented on the children's deep love of family and used these connections to initiate reading and writing activities. They incorporated the children's interests into their instruction. A culturally relevant pedagogy is predicated on teachers getting to know their students and basing their instruction on this knowledge (Gutiérrez, 2002, as cited in Sleeter, 2011). Each of the teachers came to the AWC as someone from outside the community. Each took away new cultural understandings that challenged typical stories about teaching and learning. 


\section{Discussion}

The partnerships and stories chronicled in this article offer several key takeaways about connecting with communities, establishing relationships, and building trust and respect. Trust and respect are a two-way street. The high school students taught me that in order to gain respect, one must give respect, a concept they exemplified through their service. They taught me that respect was something to be valued.

Deep respect is reflective of authentic caring (Cammarota \& Romero, 2009, as cited in Sleeter, 2011, p. 17). Contrary to how urban youth are portrayed in the media, the students who participated in the partners in service program demonstrated deep respect for community and gave freely of themselves and their time. They, in turn, gained respect for their service and their positive presence in the community.

The partners in service program taught me that it is okay to give up control. When I stepped back and facilitated, students stepped up. They created a model for connecting school, service, and community, one project at time, and our collective work was transformative. Connecting with elderly residents, building homes, planting trees, and reading books on tape demonstrated an expertise that provided a renewed sense of confidence and competence, which translated across all of the partnerships. The partners in service program transformed selves, the school, and the communities where we served. Service became the means for taking action that led to praxis.

The WLI brought literacy to people. Rather than make assumptions about women's literacies, the WLI provided education and layers of support that enabled women without pedagogical training to serve their families and communities in a leadership capacity. WLI participants saw themselves as a family, a group of women holding hands; they recognized their individual and collective strengths, which led them to reframe their identities as literate and capable (Bacon, 2014).

Lastly, the reading teachers and reading specialist candidates' experiences at the AWC took them outside the comfort of the university classroom, allowing them to connect teaching and learning with students' culture and community (cf. Sleeter, 2011). One teacher reflected that progress is wonderful, but it is so much more than numbers, percentages, and grades. Another teacher shared how at first she was afraid she wouldn't be able to help the children. She spoke to the welcoming atmosphere of the AWC, the caring shown to her by the children, 
and the support of her colleagues and teacher, which helped her settle down and concentrate on working with her students. The teachers came away thinking about the ways in which their new understandings will influence and transform their classroom practices.

These experiences speak to the role of social networks and the establishment of close ties in linking education with community. Our willingness to engage in conversation, ask questions, and listen can create important linkages that allow us to imagine future possibilities and take agentive action. Design matters. Relationships matter. The partnerships fostered a sense of shared community, bringing people together within a supportive framework that engendered transformative social change.

\section{Notes}

1. According to the Learn and Serve Fact Sheet, the statistics represent data from Fiscal Year 2010.

2. The WLI is a pseudonym.

3. The AWC is a pseudonym.

\section{References}

Albertini, V. (2009). Social networks and community support: Sustaining women in need of community-based adult education programs. New Directions for Adult and Continuing Education, 122, 23-32. doi.10.1002/ace.331

Bacon, H. R. (2014). Constructing literacy identities within communities: Women's stories of transformation. Unpublished doctoral dissertation, The University of Arizona, Arizona.

Barton, D., \& Hamilton, M. (1998). Local literacies: Reading and writing in one community. Taylor \& Francis e-Library.
Chase, S. E. (2011). Narrative inquiry: Still a field in the making. In N. K. Denzin \& Y. S. Lincoln (Eds.), The Sage handbook of qualitative methods (4th ed.) (pp. 421-434). Thousand Oaks, CA: Sage Publications, Inc.

Corporation for National and Community Service. (March 2011). Learn and Serve America [Fact sheet]. Retrieved from http:// www.nationalservice.gov/sites/default/files/ documents/factsheet_Isa.pdf

Dozier, C., Johnston, P., \& Rogers, R. (2006). Critical literacy/critical teaching: Tools for preparing responsive teachers. New York: Teachers College Press. 
Freire, P. (2000). Pedagogy of the oppressed (30th anniversary edition). New York: Continuum.

Gay, G. (2013). Teaching to and through cultural diversity. Curriculum Inquiry, 43(1), 48-70.

Gee, J. P. (2014). An introduction to discourse analysis: Theory and method (4th ed.). New York: Routledge.

Gregory, E. E., \& Compton Lilly, C. (2013). In conversation with Catherine Compton-Lilly and Eve Gregory. Language Arts, 90(6), 464-472.

Heath, S. B. (2010). Family literacy or community learning?: Some critical questions on perspective. In K. Dunsmore \& D. Fisher (Eds.), Bringing literacy home (pp. 15-41). Newark, DE: International Reading Association.

hooks, b. (2003). Teaching community: A pedagogy of hope. New York: Routledge.

Leander, K. M., Phillips, N. C., Headrick-Taylor, K., Nespor, J., \& Lewis, C. (2010). The changing social space of learning: Mapping new mobilities. Review of Research in Education, 34, 329-334.

Lin, N. (2001). Social capital: A theory of social structure and action. New York: Cambridge University Press.

Kretzmann, J. P., \& McKnight, J. L. (1993). Building communities from the inside out: A path toward finding and mobilizing a community's assets. Evanston, IL: Institute for Policy Research.

Lave, J., \& Wenger, E. (1991). Situated learning: Legitimate peripheral participation. New York: Cambridge University Press.

McDermott, R., \& Raley, J. (2009). "The tell-tale body": The constitution of disabilities in school. In W. Ayers, T. Quinn, \& D. Stovall (Eds.), Handbook of Social Justice in Education (pp. 431-445). New York: Routledge.

Moje, E. B. (2000). Critical issues: Circles of kinship, friendship, position, and power: Examining the community in community literacy research. Journal of Literacy Research, 32(1), 77-112.

Moll, L. C., Amanti, C., Neff, D., \& Gonzalez, N. (April 01, 1992). Funds of knowledge for teaching: Using a qualitative approach to connect homes and classrooms. Theory Into Practice, 31(2), 132-141.
Norton, B. (2013). Identity and language learning: Extending the conversation (2nd ed.). Tonawanda, NY: Multilingual Matters.

Orellana, M. F., \& Gutiérrez, K. D. (2006). At last: The "problem" of English learners: Constructing genres of difference. Research in the Teaching of English, 40(4), 502-507.

Purcell-Gates, V., Degener, S., \& Jacobson, E. (2001). Adult literacy instruction: Degrees of authenticity and collaboration as described by practitioners. Journal of Literacy Research, 33(4), 571-593.

Reder, S. (2007). Giving literacy away, again: New concepts of promising practice. In A. Belzer (Ed.), Toward defining and improving quality in adult basic education: Issues and challenges (pp. 255-276). New York: Routledge.

Reder, S. (2010). Adult literacy development and economic growth. National Institute for Literacy, Adult Literacy Development and Economic Growth, Washington, DC, 2006.

Short, K. (2012). Story as world making. Language Arts, 90(1), 9-17.

Short, K. G. (2013). The role of story and literature in a world of tests and standards. In K. S. Goodman, R. C. Calfee, \& Y. M. Goodman (Eds.), Whose knowledge counts in government literacy policies: Why expertise matters (pp. 113-127). New York: Routledge.

Sleeter, C. (2011). An agenda to strengthen culturally responsive pedagogy. English Teaching: Practice and Critique, 10(2), 7-23.

Small, M. L. (2009). Unanticipated gains: Origins of network inequality in everyday life. New York: Oxford University Press.

Street, B.V. (2004). Implications of the New Literacy Studies for researching women's literacy programmes. In A Robinson-Pant (Ed.), Women, literacy, and development: Alternative perspectives (pp. 57-67). New York: Routledge.

Swaminathan, R. (2007). Educating for the "real world": The hidden curriculum of community service-learning. Equity and Excellence in Education, 40(2), 134-143. doi:10.1080/10665680701246450 


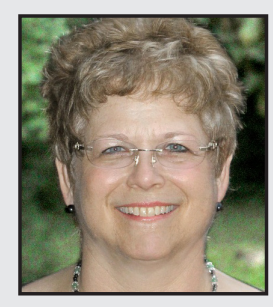

Heidi R. Bacon is an Assistant Professor of Language, Literacies, and Culture at Southern Illinois University-Carbondale. Heidi became interested in education through her volunteer work as an adult literacy tutor. She taught high school for eight years and coordinated a youth-led service learning program. She earned an MA in 2006 and a PhD in 2014 in Language, Reading, and Culture from the University of Arizona. Heidi is a strong proponent of service learning, community education, and educational equity for learners of all ages. 